\title{
Designing The Scientific Characteristics of Learning Model to Improve The Mastery of Concept on Nutrition Science II of Prospective Teachers of Physical and Health Education
}

\author{
Hartati \\ Universitas Sriwijaya, \\ Palembang, South Sumatera, Indonesia \\ hartati@fkip.unsri.ac.id \\ Herri Yusfi \\ Universitas Sriwijaya, Palembang, South \\ Sumatera, Indonesia
}

\author{
Destriani \\ Universitas Sriwijaya, \\ Palembang, South Sumatera, Indonesia
}

\begin{abstract}
This study aims to design scientific learning model characteristics to increase student's mastery of concepts of physical education and health teacher training and education science faculty. Course semester $\mathrm{V}$ on Nutrition Science II. The study was conducted over 10 weeks. The Study process was recorded as an instructional video so that students interested in attending college, in particular, calculate the nutritional athletes in various sports that were previously considered difficult. The method used in the research is the Research and Development with the systems approach adapted from Dick \& Carey. The study design is divided into three stages, namely (1) the design and development program, (2) testing and repair program, and (3) Implementation of the program. Results of this study were obtained syntax characteristic learning model to improve the scientific mastery of concepts in the course of Nutrition II. The findings in the study of student-athletes more easily calculate nutrient application using Nutri survey compared to calculate manually, while the implications of scientific learning model characteristics better than other learning models specifically calculate the nutrition of athletes on nutrition science subjects 2 . T-test results with the alpha $1 \%$ is sig $(2$-tailed $)=0.000<0.01$. It showed a difference in learning outcomes between the experimental group (implementation of learning model characterized scientifically) and control groups (direct instructional model).
\end{abstract}

Keywords: learning model, characteristics, scientific.

\section{INTRODUCTION}

Standardization of higher education in Indonesia is very important to maintain the quality of educational outcomes in order to compete in the job market locally, nationally, regionally, and internationally. Indonesia and all countries in the world are very concerned with standardization. [14] amending show that the Indonesian government wants to get the product to the ideal with a few changes [13]. NSHE according to Permenristekdikti No. 44 in 2015 consisted of national education standards (standard 8), the national standard of research, and national standards dedication to the community so that all of the standard amounts to 10 . In the national education standards are standard learning process is minimum criteria for exercising their learning in program studies for graduates to acquire the learning outcomes.

Standard learning process encompasses the characteristics of the learning process, planning, implementation, and the burden of student learning. Characteristics of the learning process consist of the interactive nature, holistic, integrative, a scientific, contextual, thematic, effective, collaborative and student-centered. Development of the characteristics of the learning process has been conducted by professors and students of Physical and Health Education (PE) Sriwijaya University (Unsri) in the form of student thesis, research reports, and numerous articles in journals and proceedings. All were related to vision Physical and Health Education (PE) is an institution that excels in human resource development, research, information, education, and innovation so that there mission who develop research in the field of education and produces educational reforms physical and health education (PE) courses.

PE challenge of the future is a great era of standardization. Alumni PE is prospective teachers will be measured regularly competence. Competency of graduates, particularly just passed is a reflection of the educational process in PE. Standardization of the characteristics of the learning process in the campus should be implemented in accordance with Permenristekdikti No. 44 in 2015, the corresponding in orientation to build the sport, dilakukakan through (1) build a sports education, (2) build a sporting achievement, and (3) building a community sports / recreational sports [5], and specifically oriented in building sports education, for get a good physical fitness to support 
learning activities, that physical fitness is the body's ability to perform activities without experiencing significant fatigue [1].

Problems faced by PE study program is the absence of a superior learning model that is believed to be implemented. For that, we need which is characterized by the development of scientific learning model of scientific learning model that has been to improve the understanding of concepts and communication skills of students. To answer the problem above, do research and development for scientific characterized design learning models to improve the mastery of concepts and communication skills of students of PE.

Researchers used a development model adapted Dick and Carey consists of three stages: (1) planning and program development, (2) testing and repair program, and (3) Implementation of the program [4]. Validation of the model performed two education experts in FKIP FKIP Sriwijaya University and the University of Lampung. To test the model performed well at two universities namely Sriwijaya University and the University of Lampung on PE courses with subjects of Nutrition 2. In the implementation phase conducted at one study program that is only Study Program Physical Education (PE) FKIP Sriwijaya University in the course of Nutrition 2, course of nutritional sciences 2 for course descriptions explain the calculation of nutrient athletes must be in accordance with physical activity undertaken by an athlete in line [2], is currently there are a number of nutritional intervention is often claimed to improve sports performance or conduct performance measurement, among a small number of nutritional interventions that are regularly available to students. It also may be important to prevent the development of nutritional deficiencies that could have a negative impact on performance [3].

\section{METHODS}

This study uses research and development with a systems approach adapted from Dick \& Carey [4]. The study design is divided into three stages, namely (1) the design and development of the program, (2) testing and repair program, and (3) Implementation of the program. The stages of design and development is first carried out a literature review and field studies, both a needs analysis conducted by studying the resources available on the Program Penjaskes which became a place of research in FKIP Sriwijaya University, third formulate research objectives, the fourth analysis of learnings and analysis of student as well as the context. After research purposes are determined, the next step is to design the structure and strategy of lectures, designing instruments, and the selection of learning materials that are essential and fundamental. Selection of essential learning materials by analyzing the curriculum and syllabus in PE study program. The learning model in the scientific characteristics of two activities-face and online learning.

\section{RESULT AND DISCUSSION}

Results of design and development acquired learning model characterized by scientific are as follows: (1) The confrontation with the problem, (2) data collection and verification, (3) data collection and experimentation, (4) organization, formulation, and explanations, (5) analysis the implementation process of learning. The results of this model design tested with the following results. The test result is limited to the physical education study program indicate where the students stated that measures learning model can be understood. Furthermore, the results of field trials (field tet) on the course of PE shownaverage gain of 0.50 with a moderate category. Video footage characteristic scientific learning model can be accessed at the following youtube website address https: // www. youtube. com / watch? $v=v k 6 f Z \_i 0 n k k$. Instructional videos recorded on the course during the learning process on the course of PE increased compared to at the beginning of the lecture. This is due to facilitate student learning activities to do the presentation the group's work on class discussion and more than 75 percent of students who participate in the learning process in the form present their thoughts, ask questions, and respond.

Learning model implementation phase conducted at one (PE) study programs with Nutritional Science subjects. Through the implementation of scientific learning model characterized by testing models developed by other similar models. In testing the model, an experimental design pretestposttest control group design was used to determine excellence in improving learning outcomes. 17 Questions that will be used in the study tested 27 students advance to the 5th semester PE Program S1 FKIP Sriwijaya University. The trial results processed by software Anatest. Anatest conclusion of the results is as follows. Mean $=25.89$, standard deviation $=6=$ 0.69 validity, reliability test $=0.82$. More than $50 \%$ matter $(21$ items) is very significant and significant, and some problems corrected before using equipment test. Results of statistical tests with alpha 1 percent Sig (2-tailed) $=0.000<0.01$. This suggests there are differences in learning outcomes between the experimental group (characteristic scientific learning model implementation) and control groups (other learning models).

It can be concluded that the scientific characteristics of learning model using the model of Dick and Carey were modified into three stages, namely (1) the design and development of the program, (2) testing and repair program, and (3) Implementation of the program. Syntax models produced in the study were (1) a confrontation with the problem, (2) data collection and verification, (3) data collection and experimentation, (4) organization, formulation, and explanations, (5) analysis of the implementation process of learning. On average n-gain achievement of the concept of four courses was 0.42 in the medium category. Test learning outcomes differences between the experimental group (Model characterized Scientific) and the control group performed at strata one of Study Program Physical Education and Health are as follows. Results of statistical tests with alpha 1 percent Sig $(2$-tailed $)=0.000<0.01$. This suggests there are differences in learning outcomes between the experimental group (characteristic scientific learning model implementation) and control groups (other learning models). Thus the concept of learning achievement of the experimental group is better than the control group.

Based on the results of previous studies that nine characteristics contained in the Permenristekdikti already done and is part of the activities of teaching models taught, research by faculty and students FKIP more oriented to the peculiarities 
of the field of study[6],[7],[8], [9]. In the era of standardization is necessary to develop a model of learning that has certain characteristics that can be used by all the existing courses in FKIP especially PE Study Program so that can be measured and implemented together. Reinforcement learning in PE Study Program should be improved and the quality of the learning process can be standardized. Many scientific studies on the learning characteristics have been carried out [10]. Develop learning blended learning with two main activities, namely learning by way of online learning and face-to-face [8]. Both activity-based learning approach to science process skills that are scientific. Today, there is a plethora of nutritional interventions which are often claimed to improve exercise performance or surrogate measurement. Amongst these nutritional interventions, there is a small number that is regularly talked about or used by student [2]. It may also be important to prevent the development of nutritional deficiencies which could have a negative impact on performance [3].

The findings in this study are students of science process skills can be improved. Conducted a study to implement cooperative learning models with the aim to improve the communication skills of students through the lesson study [9]. An important finding of the study is the activity of small discussion groups, presentations can improve the communication skills of the students [12]. The observations that evaluate the evidence and theories through inductive or experimental activities in pairs via a computer can help students find the deep structure of the empirical phenomenon without inductive activities of students tend to respond instantly and failed to find the similarity of the underlying. From some of the findings can be concluded that the scientific stage activities will facilitate students to learn procedural obtain knowledge by means of scientific methods. Mind and Handon-on can be combined simultaneously to get the learning achievements of the scientific characteristics to improve the mastery of concepts and communication skills of students of physical education and health.

\section{CONCLUSIONS}

We design the learning model using the scientific characteristics Dick and Carey model of which is modified into three stages, namely (1) the design and development of the program, (2) testing and repair program, and (3) Implementation of the program. Syntax models produced in the study were (1) a confrontation with the problem, (2) data collection and verification, (3) data collection and experimentation, (4) organization, formulation, and explanations, (5) analysis of the implementation process of learning.

Test learning outcomes differences between the experimental group (Model characterized Scientific) and the control group performed at S1 Study Program Physical Education and Health are as follows. Results of statistical tests with alpha 1 percent Sig $(2$-tailed $)=0.000<0.01$. This suggests there are differences in learning outcomes between the experimental group (characteristic scientific learning model implementation) and control groups (other learning models). Thus the concept of learning achievement of the experimental group is better than the control group. As implemented in this study with the scientific learning model using the 5 concepts: (1) The confrontation with the problem, (2) data collection and verification, (3) data collection and experimentation, (4) organization, formulation, and explanations, and (5) analysis of the implementation process of learning. The learning model was tested in the course of Nutrition 2 and the results are very significant to the other study. We recommend this model can also be used in the subject of PE-related scientific in the study program, for example, physiology, physiology Science, Anatomy and others in PE study program.

\section{REFERENCES}

[1] C.T. Mutohir, and A. Maksum, Sport Development Index Alternatif Baru Mengukur Kemajuan Pembangunan Bidang Keolahragaan. Jakarta: Bessindo Primalaras. 2007.

[2] Freeman, and H. Wiliam. Physical Education and Sport in a Changing Society. Boston: Allyn and Bacon. 2001

\{3\} Friedlander,A.L.et., Contributions of Working Muscle to Whole Body Lipid Metabolim are Altered by Exercise Intensity and Training. American Journal of Physiology. Endocrinology and Metabolism, 2007, 292 (1), pp. E. E107-16.

[4] Gall, MD, Gall, JP, \& Borg, WR, Educational Research and Introduction. Seventh Edition. USA: Pearson Education, Inc. 2003.

[5] Harsuki, Perkembangan Olahraga Terkini: Kajian Para Pakar. Jakarta: Raja grafindo Persada. 2003.

[6[ Hartono, Blended Learning Model in Practice Class IPA: Case Study on Distance Education S1 PGSD. Proceedings of the National Seminar of Chemistry and Chemical Education March Surakarta State University March 18, 2009a.

[7] Hartono, Teaching Science Process Skills in Blended Learning

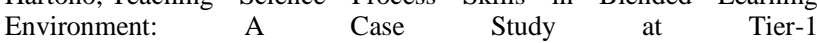
ElementaryTeacher Education. Proceedings of the Conference on Basic Education Campus University of Indonesia Sumedang October 10 to 11 , 2009b.

[8] Hartono, Assisted IPA Practicum Program Development site in Higher Education Distance S1 Primary School Teachers. Dissertation. Indonesia Education University. 2010.

[9] Hartono, The Use of Blended Learning to Delivery Practical Science Program. Proceedings of the National Seminar on Education Mathematics 2nd, Sriwijaya University in Palembang, September 17, 2011a.

[10] Hartono, Cooperative Learning Model to Improve Communication Skills Students. Proceedings of the National Seminar Lesson Study 4 at the State University of Malang in October, $2011 \mathrm{~b}$.

[11] Hartono, Multimedia Development Dental Health Education to Improve Knowledge and Attitudes "Little Doctor" in Maintaining Healthy Teeth. Journal of Educational Innovation 2, 2012, (1): 11-24.

[12] J.T.Shemwel, C.C. Chase, D. L. Schwartz. A Test of Inductive Activities for Learning and Transfer. Journal of Research in Science Teaching, Issue 1,2015, (1): 58-66.

[13] Manning, K., Effects of Exercise Training on Fat Oxidation in Untrained Overweight and Obese Females. 2011

[13] Permendikbud. On National Standards for Higher Education. No. 49 2014.

[14] Permenristekdikti, On National Standards for Higher Education. No. 44. 2015. 